\title{
The Principles Governing the Lung Structure and Function
}

\author{
Yotanna Dalavanga* \\ Department of Medicine, University of Ioannina, Greece
}

Submission: May 01, 2017; Published: May 04, 2017

*Corresponding author: Yotanna Dalavanga, Associate Professor of Anatomy-Histology-Embryology, School of Health Sciences, Department of

Medicine, University of Ioannina, Ioannina,Greece, Email: yotannad@gmail.com

Abstract

Three main tissues, epithelium, endothelium and interstitium, construct the highly complicated yet delicate lung parenchyma. Cartilage and distinct units of typical connective tissue, support the airways walls. Smooth muscles contribute in the structure and regulation of the lung function. Parietal and visceral pleura mesothelium and the in between film of fluid in the pleural cavity, ensures that the lungs move smoothly inside the thoracic cavity

\section{Introduction}

There is a unique feature in the lung; the airways form a continuum from the trachea to the alveoli. There are no interruptions or abrupt transitions, but rather a smooth gradual transformation from the wide, strong trachea, through bronchi and bronchioles, to the minuscule delicate alveoli. In the same way the interstitium comprises a continuum, which ensures that the lung functions as a whole entity. The cause of this continuity is the lungs' own embryonic development. The lungs develop from a single endodermic outgrowth of the foregut, growing in the mass of the surrounding mesenchyme. The dichotomous branching of the lung bud initially and its branches for about 19 consecutive generations, ends up with the creation of a tree-like structure of connected airways, opening to millions of alveoli. The surrounding mesenchyme gives rise to the components of the airways wall and to the interstitium, the continuum of the delicate connective tissue that surrounds the alveoli. It is this continuity of the interstitium that dictates the mechanical properties of the lung, which, that way, operates as a functional syncitium [1-3].

The continuity of the airways also implies the type of their epithelium, which must run smoothly throughout the bronchial tree to the alveoli, without abrupt changes. Since the functional epithelium of the respiratory units needs to be as thin as possible, it must be comprised of a single layer of the finest squamous type. Therefore the whole respiratory epithelium must be arranged in a single layer. Different functional needs throughout the conducting airways and the alveoli result in differentiations of the epithelium in certain locations, in terms of cell shape and function; yet the common feature in all parts is that the epithelium is a mosaic of lining and secretory cells arranged in one layer. The proximal airway is characterized by increased thickness of the epithelial cell layer, taller cells and a pseudo stratified appearance [4]. In the distal airways the epithelium becomes progressively thinner, until it is comprised of low cuboidal cells at the level of terminal bronchioles.

The respiratory epithelium creates a barrier, acts as a secretory organ and retains the capacity to repair following injury. The epithelial cells, by virtue of forming the luminal lining of the airways, are in an ideal position to interact with environmental constituents and modulate the response of other airway cells. There is a prominent basement membrane under the epithelium. Mucus and serous glands are abundant in the submucosa of the large airways but decrease along with the diameter and disappear in the level of bronchioles.

The connective tissue that surrounds the branching airways dissolves in the delicate interstitial lung tissue, which creates a scaffold for the alveoli and the uncountable capillaries of the alveolar walls. This delicate structure of the 300 million alveoli covers a surface of $140 \mathrm{~m} 2$. The strong presence of elastic fibres determines the distensibility of the system. Smooth muscle fibres create a contractile layer under the mucosa up to the level of alveoli. They are involved in the regulation of the caliber of the airway's lumen through contraction, and consequently they are involved in the regulation of ventilation [5]. 
Cartilage strengthens the walls of large airways; its amount is gradually decreasing along with the diameter of the airway and no cartilage is detected in the bronchioles. Changes in the structure of any of these components lead to disturbances of the normal function. There is a lot more to be learned about the structure and function of the normal lung. The study of the lung in health, disease and experimental conditions, is of great importance in order to move further in the understanding of the pathogenetic mechanisms underlining the diseases of the respiratory system and from there to the diagnosis, the treatment and more importantly their prevention.

\section{References}

1. Crystal RG, West JB (1991) The Lung; Scientific Foundations. Raven Press.
2. Junqueira LC, Carneiro J (2003) Basic Histology. Lange Medical Books McGrow-Hill (10 ${ }^{\text {th }}$ Edn.), India.

3. Burkitt HG, Young B, Heath JW. Wheater's Functional Histology. Churchill-Livinstone, ( $3^{\text {rd }}$ Edn.), London, UK.

4. Ian De Proost, Isabel Pintelon, Inge Brouns, Alfons BA Kroese, Daniela Riccardi, et al. (2008) Functional Live Cell Imaging of the Pulmonary Neuroepithelial Body Microenvironment. Am J Respir Cell Mol Biol 39(2): 180-189.

5. Evans CM, Williams OW, Tuvim MJ, Nigam R, Mixides GP, et al. (2004) Mucin Is Produced by Clara Cells in the Proximal Airways of AntigenChallenged Mice. Am J Respir Cell Mol Biol 31(4): 382-394.

\section{Your next submission with Juniper Publishers} will reach you the below assets

- Quality Editorial service

- Swift Peer Review

- Reprints availability

- E-prints Service

- Manuscript Podcast for convenient understanding

- Global attainment for your research

- Manuscript accessibility in different formats ( Pdf, E-pub, Full Text, Audio)

- Unceasing customer service

Track the below URL for one-step submission https://juniperpublishers.com/online-submission.php 